\title{
Ytringsfrihet og terrorisme
}

\author{
Kristian Skagen Ekeli \\ Professor, Universitetet i Stavanger \\ E-post: kristian.ekeli@uis.no
}

English abstract p. 281

\begin{abstract}
Bør liberale demokratier forby oppfordringer til terrorisme? Selv om det finnes interessante argumenter for å forby slike oppfordringer, argumenterer forfatteren i denne artikkelen mot et forbud.
\end{abstract}

\section{Innledning ${ }^{1}$}

I liberale demokratier betraktes gjerne retten til politisk ytringsfrihet som en grunnleggende verdi, og som en vesentlig dimensjon ved borgeres rett til politisk deltagelse. I dag er det dessuten en vanlig antagelse at politisk ytringsfrihet er et krav til demokratisk legitimitet - det vil si et krav til rettmessig demokratisk utøvelse av politisk tvangsmakt. Til tross for disse antagelsene, finnes det både $\mathrm{i}$ Norge og mange andre europeiske land, som vanligvis regnes som liberale demokratier, forbud mot visse former for ekstreme politiske ytringer - som hatefulle ytringer og oppfordringer til terrorisme. I disse statene synes det ikke å være en utbredt antagelse at slike forbud representerer krenkelser av retten til ytringsfrihet i liberale demokratier. Det synes heller ikke å være en utbredt oppfatning at slik sensur av politiske ytringer undergraver legitimiteten til demokratiske styringssystemer.
I denne artikkelen vil jeg diskutere spørsmålet om liberale demokratier bør beskytte offentlige politiske ytringer som oppfordrer til terrorisme. Selv om det finnes flere interessante argumenter for et forbud mot oppfordringer til terrorisme, så vil jeg argumentere for en sterk beskyttelse av ekstreme politiske ytringer, som oppfordringer til terrorisme. Det vil si at i et liberalt demokrati bør retten til politisk ytringsfrihet beskytte oppfordringer til terrorisme - med mindre slike ytringer skaper en sannsynlig og overhengende fare for alvorlige ulovlige handlinger eller aktiviteter, som terrorisme eller terrorhandlinger. Min posisjon er basert på den antagelsen at ytringsfrihetens kjerneverdi (eller normative kjernegrunnlag) $i$ et liberalt demokrati er å beskytte og fremme frie og velinformerte deliberasjonsprosesser - både intrapersonlige og interpersonlige deliberasjonsprosesser. $^{2}$ Denne begrunnelsen for ytringsfriheten har både instrumentelle og ikke-instrumentelle aspekter, som har vikti- 
ge implikasjoner med tanke på rekkevidden og statusen (dvs. vekten) til retten til ytringsfrihet.

Mitt forsvar av en sterk beskyttelse av offentlige politiske ytringer som oppfordrer til terrorisme, er inspirert av den såkalte Brandenburgtesten, som spiller en viktig rolle $\mathrm{i}$ amerikansk konstitusjonell rett. Denne testen innebærer at det kun er tillatelig å sensurere eller forby politiske ytringer hvis de skaper (og har til hensikt å skape) en sannsynlig og overhengende fare for ulovlige handlinger - for eksempel straffbare voldshandlinger som terrorisme. ${ }^{3}$ I motsetning til Brandenburgtesten, vil jeg ikke utelukke at man kan tenke seg visse ekstraordinære situasjoner hvor det kan være tillatelig å sensurere eller forby politiske ytringer, selv om de aktuelle ytringene ikke skaper en sannsynlig og overhengende fare. Problemet om tillatelige begrensinger av politiske ytringer er komplekst, og jeg tror ikke at en test (eller et prinsipp) kan utgjøre en basis for å ta stilling til hva som vil være tillatelige restriksjoner på politiske ytringer i alle saker eller omstendigheter. Mitt poeng er imidlertid at det er en sterk presumpsjon i favør av Brandenburgtesten (eller en lignende test/prinsipp) i lys av ytringsfrihetens kjerneverdi. Jeg vil argumentere for at det hviler en tung begrunnelsesbyrde på de som forsvarer avvik fra denne testens strenge betingelser, og som forsvarer synspunktbaserte restriksjoner på politiske ytringer - inkludert ekstreme politiske ytringer som oppfordrer til terrorisme.

Denne artikkelens problemstilling vil diskuteres gjennom følgende steg: I del 2 vil jeg forklare nærmere hva jeg mener med offentlige politiske oppfordringer til terrorisme. Del 3 vil presentere det jeg anser for å være de viktigste og mest interessante argumentene for et forbud mot oppfordringer til terro- risme. I del 4 vil jeg legge frem mitt forsvar av en sterk beskyttelse av politiske ytringer som oppfordrer til terrorisme.

\section{Politiske ytringer og oppfordringer til terrorisme}

Utgangspunktet for min diskusjon er en vid forståelse av politiske ytringer. Politiske ytringer vil referere til alle ytringer som er relevante for politisk overveielse eller diskusjon. Det er ytringer som er relevante for både intrapersonlig og interpersonlig deliberasjon om politiske saker, problemer og ideer, og som har betydning for det politiske liv. Denne forståelsen av politiske ytringer vil omfatte religiøse og ideologiske synspunkter og ideer som er relevante for politisk deliberasjon - for eksempel oppfordringer til hellig krig eller Jihad.

Det finnes i dag en rekke forskjellige definisjoner av terrorisme. For denne artikkelens formål, vil jeg ta utgangspunkt $\mathrm{i}$ at «terrorisme» i typiske tilfeller viser til bruk av vold mot uskyldige personer med den hensikt å skape frykt for å oppnå politiske mål. Terrorisme er således en politisk strategi eller taktikk, men de politiske målene kan ha en sekulær og/eller religiøs basis eller motivasjon. På denne bakgrunnen vil termen «oppfordringer til terrorisme» referere til ytringer som oppfordrer til bruk av vold mot uskyldige personer med den hensikt å skape frykt for å oppnå politiske mål. I likhet med Storbritannias Terrorism Act 2006, vil jeg trekke et skille mellom direkte (eksplisitte) og indirekte (implisitte) oppfordringer til terrorisme - hvor sistnevnte form for oppfordring hovedsakelig refererer til forherligelse eller glorifisering av terrorisme (f.eks. forherligelse av selvmordsaksjoner). ${ }^{4}$ 
Man kan for denne artikkelens formål trekke et skille mellom to kategorier oppfordringer til terrorisme: offentlige politiske oppfordringer og private politiske oppfordringer. I likhet med Kent Greenawalt, vil jeg anta at offentlig tilgang til ytringens innhold eller budskap er avgjørende for å trekke denne offentlig-privat-distinksjonen. "The crucial factor for public speech is that the message be communicated in a way in which its content can become known to a wide audience». ${ }^{5}$ En privat oppfordring har derimot kun til hensikt å nå noen få nøye utvalgte personer, som for eksempel når religiøse eller politiske ledere henvender seg til noen få utvalgte tilhengere bak lukkede dører eller i lukkede internettfora. Jeg vil fokusere på offentlige politiske oppfordringer til terrorisme. ${ }^{6}$ Det er denne kategorien oppfordringer til terrorisme jeg vil argumentere for at bør ha en sterk beskyttelse.

\section{Argumenter for et forbud mot oppfordringer til terrorisme}

I motsetning til USA, har en rekke liberale demokratier (spesielt i Europa) lover som forbyr oppfordringer til terrorisme. ${ }^{7}$ Noen stater forbyr kun direkte oppfordringer til terrorisme, mens andre forbyr både direkte og indirekte oppfordringer (f.eks. forherligelse eller glorifisering av terrorisme) ${ }^{8}$ Norge er et av de landene som forbyr både direkte og indirekte oppfordringer. ${ }^{9}$ I denne delen vil jeg presentere tre argumenter for forbud mot oppfordringer til terrorisme.

\subsection{Argumentet basert på å forbindre alvorlig skade}

Hovedideen i det jeg vil kalle argumentet basert på å forhindre alvorlig skade, er at staten har en plikt til å beskytte sine borge- res sikkerhet, og at den bør forby oppfordringer til terrorisme for å forhindre, eller redusere sannsynligheten for, de alvorlige skader/konsekvenser som slike ytringer kan forårsake - det vil si terrorisme og voldelig radikalisering. ${ }^{10}$ Det er flere måter å utvikle detaljene i dette argumentet. Uansett tror jeg at ulike versjoner av dette argumentet utgjør en svært viktig dimensjon av begrunnelsen for de forbud mot oppfordringer til terrorisme som man i dag finner i en rekke liberale demokratier. En måte å utvikle dette argumentet på, forløper slik:

(1) Staten har en plikt til å ivareta og beskytte borgernes sikkerhet - for eksempel beskytte dem mot straffbare voldshandlinger som terrorisme.

(2) Ytringer (dvs. spredningen av ideer og informasjon) former personers tanker og preferanser, og de påvirker deres handlinger og adferd. Politiske og religiøse ideer og synspunkter påvirker for eksempel hvilke mål og handlinger personer betrakter som verdt å forfølge. Fra et historisk synspunkt er dette tydelig med tanke på den betydelige kraft ulike politiske og religiøse ideer eller ideologier har og har hatt.

(3) Uavhengig av talerens intensjon (eller hensikt), vil offentlige oppfordringer til terrorisme øke sannsynligheten for at noen, en eller annen gang, på et eller annet sted, vil bli overtalt eller oppmuntret til å begå terrorhandlinger eller støtte (på forskjellige måter) terroristorganisasjoner.

(4) Gitt de empiriske antagelsene (2) og (3), er det rimelig å anta at et forbud mot offentlige oppfordringer til terrorisme vil redusere sannsynligheten for terrorhandlinger (eller antallet terrorhandlinger), og at et forbud vil bidra til å forhindre voldelig radikalisering.

(5) Siden terrorisme kan forårsake spesielt alvorlige skader (i visse tilfeller katastro- 
fale skader), er en føre var-strategi på sin plass med tanke på oppfordringer til terrorisme - selv om risikoen er usikker, og sannsynligheten for at slike ytringer vil lede til terrorhandlinger er lav. Den kausale relasjonen mellom oppfordringer til terrorisme og de skader slike oppfordringer kan forårsake, er preget av usikkerhet. I lys av hvor alvorlige de potensielle skadene er, så er imidlertid en føre var-strategi på sin plass.

(6) Gitt de ovennevnte normative og empiriske antagelsene (dvs. (1)-(5)), bør stater forby oppfordringer til terrorisme som en føre var-strategi, som har til hensikt å forhindre, eller redusere sannsynligheten for, terrorisme og voldelig radikalisering.

I lys av det ovennevnte resonnementet, kan det gi god mening ikke bare å forby direkte oppfordringer til terrorisme, men også indirekte oppfordringer, som forherligelse eller glorifisering av terrorisme. Grunnen er at også slike ytringer kan ha en farlig påvirkningskraft og bidra både til terrorisme og voldelig radikalisering.

Selv om dette argumentet synes å ha noe for seg, så møter det noen viktige problemer og innvendinger som må vurderes nærmere for å ta stilling til argumentets styrke. ${ }^{11}$

(i) I den liberale tradisjonen i politisk filosofi er det bred tilslutning om at staten har en plikt til å beskytte sine borgeres sikkerhet. Med tanke på relasjonen mellom denne plikten og retten til ytringsfrihet, aktualiseres imidlertid to svært viktige spørsmål: Kan denne plikten rettferdiggjøre sensur av ekstreme politiske ytringer $i$ et liberalt demokrati, og er slik sensur av politiske ytringer en krenkelse (eller en urettmessig restriksjon) av borgernes rett til politisk ytringsfrihet? For å ta stilling til disse spørsmålene, er det nødvendig å vurdere rekkevidden og sta- tusen (dvs. vekten) til retten til ytringsfrihet nærmere. ${ }^{12}$ Jeg vil komme tilbake til dette temaet nedenfor og i del 3.3. og 4.

(ii) Argumentet basert på å forhindre alvorlig skade hviler på antagelsen om at staten bør forby oppfordringer til terrorisme, fordi slike ytringer har en farlig påvirkningskraft som kan lede til farlige endringer eller forandringer i folks oppfatninger og adferd. Tanken er at siden oppfordringer til terrorisme på denne måten kan forårsake svært alvorlige skader, så er det tillatelig for staten å kontrollere folks informasjonskilder og deres tilgang til visse farlige politiske synspunkter og ideer. Denne ideen om at det er tillatelig for et liberalt demokrati å forby politiske synspunkter på grunn av deres farlige påvirkningskraft er kontroversiell. Denne antagelsen er i konflikt med det jeg vil kalle prinsippet om tilhørerautonomi, som kan formuleres slik: Enhver borger bør ha frihet til å høre, vurdere og respondere på andres politiske synspunkter og argumenter, og de bør ha frihet til å gjøre seg opp sin egen oppfatning om deres styrker og svakheter. Dette prinsippet innebærer at det er prima facie galt for staten å sensurere politiske synspunkter fordi myndighetene frykter at folk vil bli påvirket av de aktuelle synspunktene. Man kan argumentere for at dersom staten sensurerer politiske ytringer på et slikt grunnlag, så viser den ikke respekt for personer som selvstendig tenkende aktører og deres rett til tankefrihet. (Dette argumentet utdypes i del 4.)

(iii) Man kan sette spørsmålstegn ved hvorvidt (og i hvilken grad) en føre var-tilnærming kan forsvares på en overbevisende måte når det gjelder sensur av politiske ytringer som betraktes som farlige, fordi de kan forårsake alvorlig skade. I sitt forsvar av en versjon av Brandenburgtesten, legger 
John Rawls frem følgende refleksjoner, som det er svært viktig å ta i betraktning i denne sammenhengen:

[I]t is of no particular moment whether political speech is dangerous, since political speech is by its nature often dangerous. This is because the free public use of reason applies to the most fundamental questions, and the decisions made may have grave consequences. ... And of course political speech which expresses doctrines we reject, or find contrary to our interests, all too easily strikes us as dangerous. ${ }^{13}$

Det er mange doktriner og ideer - både politiske og religiøse - som har motivert, og som fortsatt motiverer individer og grupper til ulike typer alvorlige voldshandlinger som terrorisme og krig. Historisk sett gjelder dette blant annet de doktrinene og ideene som fremsettes i Bibelen, Koranen og Karl Marx' (og andre marxisters) verk. Bør liberale demokratier forby Bibelen, Koranen og marxistiske bøker på grunn av deres farlige påvirkningskraft som en føre var-strategi for å unngå alvorlige voldshandlinger?

(iv) Når det gjelder spørsmålet om hvor effektivt et forbud mot oppfordringer til terrorisme vil være, så kan man sette spørsmålstegn ved den empiriske antagelsen (4). Det vil si antagelsen om at et forbud mot offentlige oppfordringer til terrorisme vil redusere sannsynligheten for terrorhandlinger (eller antallet terrorhandlinger), og at et forbud vil bidra til å forhindre voldelig radikalisering. Et forbud vil ikke fjerne ekstremistisk tankegods. Det vil heller ikke stoppe ytringer som oppfordrer til terrorisme. Den viktigste konsekvensen av et forbud er antagelig å fordrive denne typen ytringer inn i lukkede rom hvor de kan bli stående uimot- sagt, og dette kan ha svært uheldige konsekvenser på flere måter. For det første kan det gjøre det vanskeligere å identifisere potensielle terrorister eller potensielle sikkerhetstrusler. For det andre kan dette i visse miljøer forsterke den politiske eller religiøse ekstremismen.

Som en respons på de ovennevnte problemene og innvendingene, kan de som forsvarer et forbud mot oppfordringer til terrorisme argumentere for at et bedre (eller det beste) forsvar av et forbud, er å kombinere argumentet basert på å forhindre alvorlig skade med argumentet om at oppfordringer til terrorisme er verdiløse ytringer som ikke fortjener beskyttelse. Det sistnevnte argumentet vil presenteres i neste del.

\subsection{Argumentet basert på ytringers verdi}

Det andre argumentet for et forbud innebærer at oppfordringer til terrorisme ikke bør beskyttes (eller ikke fortjener beskyttelse) fordi slike ytringer er verdiløse. Denne posisjonen hviler hovedsakelig på antagelsen om at slike ytringer ikke bidrar til sannhetssøken gjennom rasjonell diskusjon og meningsutveksling. Dette vil blant annet si at slike ekstreme ytringer ikke bidrar til å oppdage feil (f.eks. feilaktige meninger og synspunkter) eller fremme forståelse, velbegrunnet kunnskap og sannhet. Noen vil for eksempel argumentere for at det er liten - eller ingen - grunn til å forvente at ytringer som oppfordrer til terrorisme, vil bidra til sin egen gjendrivelse. Snarere tvert imot, er det mer sannsynlig at denne typen ytringer vil bidra til voldelig radikalisering.

En sentral idé er her at oppfordringer til terrorisme ikke bidrar til rasjonell politisk deliberasjon eller overveielse om politiske saker, problemer og ideer i et liberalt demokrati. Tanken er at slike ytringer utelukken- 
de representerer farlige ekstreme ideer og synspunkter som både er irrasjonelle og umoralske, og de fortjener ikke seriøs debatt og refleksjon. Fra et slikt ståsted vil ikke et forbud sensurere verdifull utveksling av ideer og meninger, som er viktig for fruktbar offentlig debatt. Et forbud vil snarere tvert om fjerne synspunkter og ideer som «forgifter» eller «forurenser» offentlig debatt og mulighetsbetingelsene for rasjonell diskusjon og overveielse i et demokrati.

Den foregående posisjonen om verdien av oppfordringer til terrorisme er reflektert både i rettsteoretisk litteratur og i offentlig debatt. Den kjente juristen og rettsteoretikeren Richard Posner har nylig argumentert for at oppfordringer til terrorisme - som oppfordringer til hellig krig - ikke har noen sosial verdi i et liberalt demokrati: "In the context of American society, the advocacy of holy war against the United States, the West generally, our allies in Asia and Africa, Western values, and modernity in general has no redeeming social value; it is merely crazy and murderous». ${ }^{14}$ Den amerikanske juristen og spaltisten i The Washington Times, Bruce Fein, forsvarer en lignende posisjon:

Freedom of speech would be undisturbed by criminalizing the condoning or glorifying of terrorism. The latter celebrates the indiscriminate employment of violence or coercion against civilian populations to effectuate political change. The overriding purpose of free speech, in contrast, is to protect reasoned discourse in the search for political truths. No social good is advanced by condoning or acclaiming terrorists, but their social danger is alarming: namely, motivating the impressionable, alienated or semi-demented to suicide bombings or sister villainies. $^{15}$
I motsetning til de posisjonene som er skissert i denne delen, er jeg uenig $i$ at oppfordringer til terrorisme er uten verdi i liberale demokratier. Ekstreme politiske ytringer som oppfordringer til terrorisme - kan ha betydelig verdi med hensyn til både intrapersonlige og interpersonlige deliberasjonsprosesser. Jeg vil komme tilbake til dette temaet i del 4.

\subsection{Respektargumentet}

Respektargumentet innebærer at respektbenektende ytringer faller utenfor rekkevidden til retten til ytringsfrihet. Respektbenektende ytringer viser her til ytringer som benekter (eller eksplisitt avviser) at alle personer bør betraktes og behandles som frie og likeverdige. Både Steven Heyman og Jonathan Quong har nylig utviklet ulike versjoner av et slikt respektargument. ${ }^{16}$ Selv om Heyman og Quong hovedsakelig fokuserer på hatefulle ytringer i sine respektive diskusjoner, ${ }^{17}$ er det liten tvil om at respektargumentet også har interessante implikasjoner med tanke på oppfordringer til terrorisme. Respektargumentet innebærer at direkte og indirekte oppfordringer til terrorisme ikke bør beskyttes i den grad slike ytringer er å betrakte som respektbenektende ytringer. I det følgende vil jeg skissere hovedideene i Heyman og Quongs respektargumenter, og forklare hvordan deres argumenter kan utgjøre et grunnlag for et forbud mot oppfordringer til terrorisme.

Hovedideen hos både Heyman og Quong er at retten til ytringsfrihet har en unntaksklausul - en respektklausul - som begrenser denne rettighetens rekkevidde (dvs. hva retten til ytringsfrihet er en rett $t i l)$. Tanken er at $\mathrm{P}$ har en rett til ytringsfrihet med unntak av situasjoner hvor P bruker eller forsøker å bruke denne rettigheten på en måte som er i 
klar konflikt med (eller krenker) den normative ideen om å anerkjenne og respektere andre som frie og likeverdige personer. Ideen om at personer er frie viser hovedsakelig til at de bør betraktes og behandles som selvstendig tenkende aktører med (a) evnen til rasjonell og moralsk overveielse, og (b) evnen til å vurdere og velge hva som utgjør et meningsfullt og verdifullt liv. Ideen om at personer er likeverdige (eller like) viser til at de bør tilskrives lik moralsk status - uavhengig av kjønn, hudfarge, etnisk opprinnelse, livssyn, osv..

Heyman og Quongs posisjon aktualiserer spørsmålet om hvorfor respektbenektende ytringer faller utenfor rekkevidden til retten til ytringsfrihet. Deres svar på dette spørsmålet er ikke identiske, men har, slik jeg tolker dem, visse fellestrekk. Fellesnevneren i Heyman og Quongs respektargumenter kan, slik jeg ser det, presenteres slik:

(1) Alle personer bør betraktes og behandles som frie og likeverdige. Liberale demokratier har en plikt til å betrakte individer på denne måten, og borgere har en tilsvarende plikt til å anerkjenne og respektere hverandre som frie og likeverdige personer.

(2) Den normative ideen om at alle personer bør betraktes og behandles som frie og likeverdige utgjør det normative kjernegrunnlaget for begrunnelsen av personers eller borgeres liberal-demokratiske rettigheter (dvs. politiske og sivile rettigheter).

(3) Det normative kjernegrunnlaget begrenser rekkevidden for (valgbeskyttende) liberal-demokratiske rettigheter ${ }^{18}$ - i den forstand at man ikke har en rett til å bruke (eller forsøke å bruke) en rettighet på en måte som er i klar konflikt med liberal-demokratiske rettigheters kjernegrunnlag. ${ }^{19}$ Det vil si at personer ikke har en rett til å bruke eller forsøke å bruke en rettighet på en måte som er i klar konflikt med den normative ideen om å anerkjenne og respektere andre som frie og likeverdige.

(4) Respektbenektende ytringer er i klar konflikt med liberal-demokratiske rettigheters kjernegrunnlag, fordi slike ytringer avviser ideen om at alle bør betraktes og behandles som frie og likeverdige personer.

(5) Respektbenektende ytringer faller derfor utenfor rekkevidden til retten til ytringsfrihet generelt, og retten til politisk ytringsfrihet spesielt. ${ }^{20}$

Det synes å være rimelig å betrakte mange former for oppfordringer til terrorisme som respektbenektende ytringer. En viktig grunn til dette er at oppfordringer til terrorisme synes å uttrykke (eksplisitt eller implisitt) en mangel på respekt for den moralske statusen til de potensielle målene for terrorhandlinger. Direkte og indirekte oppfordringer til å drepe uskyldige sivile synes å være en form for eksplisitt benektelse av at alle personer har lik moralsk status. Mer generelt kan man si at målene for terrorhandlinger betraktes eller behandles som mennesker med lavere moralsk status enn andre, og at de kan gjøres til gjenstand for vold og mord for å tjene politiske mål.

Det skisserte respektargumentet utgjør en interessant basis for forbud mot oppfordringer til terrorisme som det er verdt å ta alvorlig. Når det er sagt, så er jeg uenig i at respektbenektende ytringer faller utenfor rekkevidden til retten til politisk ytringsfrihet. Selv om man aksepterer de abstrakte normative ideene om at borgere bør betraktes som frie og likeverdige personer og at rettigheter er basert på respekt for personers autonomi og verdighet, så er det langt derifra åpenbart at respektbenektende ytringer faller utenfor ytringsfrihetens rekkevidde. $\AA$ trekke Heyman og Quongs konklusjon på 
grunnlag av disse abstrakte antagelsene (eller premissene) er kontroversielt, og en rekke fremstående liberale filosofer vil avvise denne slutningen. ${ }^{21}$ Man kan være enig i at alle personer i et liberalt demokrati bør betraktes og behandles som frie og likeverdige, men likevel avvise Heyman og Quongs syn på rekkevidden til retten til politisk ytringsfrihet. I neste del vil jeg legge frem mitt forsvar av en slik posisjon.

\section{Argumenter for en sterk beskyttelse av oppfordringer til terrorisme}

I denne delen vil jeg argumentere for en sterk beskyttelse av ekstreme politiske ytringer, som oppfordringer til terrorisme. Det vil si at hvis alt annet står likt, så bør liberale demokratier beskytte politiske ytringer som oppfordringer til terrorisme - med mindre slike ytringer skaper (og har til hensikt å skape) en sannsynlig og overhengende fare for alvorlige ulovlige handlinger eller aktiviteter som terrorisme. Min posisjon er basert på den antagelsen at ytringsfrihetens kjerneverdi (eller normative kjernegrunnlag) i et liberalt demokrati er å beskytte og fremme frie og velinformerte deliberasjonsprosesser - både intrapersonlige og interpersonlige ${ }^{22}$ deliberasjonsprosesser.

\subsection{Ytringsfrihetens kjerneverdi}

Utgangspunktet for min begrunnelse for retten til ytringsfrihet er at respekt for personer som tenkende aktører krever en beskyttelse av frie og velinformerte intrapersonlige og interpersonlige deliberasjonsprosesser. ${ }^{23}$ Dette betyr mer presist at beskyttelsen av fri og velinformert deliberasjon er avgjørende for å respektere personers autonomi både som talere og tilhørere. Det vil si å respekte- re personers status som moralske aktører eller selvstendig tenkende aktører, som har (a) evnen til rasjonell og moralsk refleksjon, (b) evnen til å gjøre seg opp egne oppfatninger for eksempel om hva som er verdifullt og hvilke mål det er verdt å forfølge, og (c) evnen til å uttrykke eller formidle sine tanker, ideer og overbevisninger og forsvare dem mot andres kritikk. (Jeg vil komme nærmere tilbake til denne ideen om respekt for personer og dens rolle i en politisk kontekst i del 4.2 og 4.3). Denne relasjonen (eller forbindelsen) mellom respekt for personer og deliberasjon utgjør en viktig grunn for antagelsen om at ytringsfrihetens kjerneverdi er å beskytte og fremme frie og velinformerte intrapersonlige og interpersonlige deliberasjonsprosesser.

Ytringsfrihetens kjerneverdi eller normative kjernegrunnlag kan utvikles videre ved å analysere og klargjøre hvilke viktige interesser og verdier som denne rettigheten har til hensikt å beskytte og fremme i et liberalt demokrati. Disse interessene og verdiene er nært knyttet til den skisserte ideen om respekt for personer - i den forstand at beskyttelsen av disse interessene og verdiene på ulike måter er vesentlige for å respektere personer som tenkende aktører. I denne sammenhengen kan man argumentere for at ytringsfrihetens kjerneverdi har minst tre viktige dimensjoner, og disse er relatert på forskjellige måter: (1) Kommunikative interesser refererer hovedsakelig til interesser knyttet til å spre og formidle ideer, synspunkter og informasjon til et bredt publikum, og interesser relatert til å påvirke andres tanker og adferd. (2) Deliberative interesser er relatert til personers interesse i å ha gode rammevilkår for å forme og utvikle sine preferanser, mål og oppfatninger (både politiske oppfatninger og oppfatninger om 
hva som utgjør et meningsfullt og verdifullt liv). Den deliberative dimensjonen omfatter interesser knyttet til å bli eksponert for informasjon og konkurrerende doktriner og ideer. Denne dimensjonen dreier seg også om verdien av å ha muligheten til å vurdere og diskutere synspunkter og ideers styrker og svakheter for å gjøre seg opp en egen oppfatning om hva man skal tro på og hvordan man skal handle i ulike sammenhenger. $^{24}$ (3) Demokratiske verdier er verdier knyttet til demokratiske institusjoner og prosesser som retten til ytringsfrihet har til hensikt å beskytte og fremme. To slike verdier er for denne artikkelens formål spesielt viktige. Den første er verdien av å ha velfungerende og rettferdige demokratiske prosesser og institusjoner. Den andre er verdien av å ha rammevilkår som muliggjør velinformert intrapersonlig og interpersonlig deliberasjon om politiske doktriner og ideer. Slike rammevilkår forutsetter at borgere har tilgang til, og blir eksponert for, alternative og konkurrerende ideer og argumenter, som blir fremsatt med overbevisning og kraft på en måte som kan synliggjøre deres styrker og svakheter og stimulere til kritisk overveielse. $^{25}$

Ytringsfrihetens skisserte kjerneverdi eller kjernegrunnlag har både instrumentelle og ikke-instrumentelle aspekter. Det instrumentelle aspektet fokuserer på hvordan ytringsfriheten utgjør et vesentlig institusjonelt middel for å beskytte og fremme frie og velinformerte deliberasjonsprosesser og viktige interesser og verdier. Det ikke-instrumentelle eller statusbaserte aspektet ved begrunnelsen for ytringsfrihet tar utgangspunkt i visse antagelser om rettighetshaveres egenskaper og status. Personer har visse egenskaper (f.eks. evnen til rasjonell og moralsk deliberasjon eller overveielse og evnen til å uttrykke sine tanker og overbevisninger) som berettiger og påkaller respekt. Disse respektpåkallende egenskapene utgjør en basis for å tilskrive personer en rett til ytringsfrihet, og krenkelser av denne rettigheten vil være etisk sett gale uavhengig av konsekvensene av å beskytte rettigheten. En sentral idé knyttet til dette aspektet er å vise respekt for personers status eller verdighet som tenkende aktører eller moralske aktører. $^{26}$

På grunnlag av ytringsfrihetens kjerneverdi kan man utvikle (minst) tre argumenter for en sterk beskyttelse av oppfordringer til terrorisme: (1) Argumentet basert på tankefrihet, (2) argumentet basert på demokratisk legitimitet og (3) argumentet basert på ekstreme politiske ytringers (positive) verdi. De to første argumentene kan betraktes som innvendinger mot såkalte synspunktbaserte restriksjoner på politiske ytringer. ${ }^{27}$ Synspunktbaserte restriksjoner har gjerne til hensikt å sensurere ytringer fordi synspunktene eller ideene som uttrykkes betraktes som farlige. De er vanligvis motivert av en frykt for de konsekvenser mottagelsen av visse synspunkter kan få - det vil si en frykt for at et synspunkt har en farlig påvirkningskraft.

\subsection{Argumentet basert på tankefribet}

Ytringsfrihetens kjerneverdi utgjør en basis for et krav om synspunktnøytralitet - det vil si en sterk presumpsjon mot synspunktbaserte restriksjoner på politiske (og religiøse) ytringer - inkludert ekstreme politiske ytringer som oppfordringer til terrorisme. Et viktig argument for synspunktnøytralitet er basert på antagelsen om at det er en nær sammenheng mellom retten til tankefrihet og ytringsfrihetens kjerneverdi (eller kjernegrunnlag). Beskyttelsen av fri intrapersonlig 
og interpersonlig deliberasjon er uatskillelig fra retten til tankefribet. Denne rettigheten omfatter tanke- og trosfrihet på alle områder - det vil for eksempel si tanke- og trosfrihet i religion, politikk, vitenskap, filosofi, kunst og litteratur. Retten til tankefrihet innebærer også frihet til å leve i overensstemmelse med de krav ens samvittighet stiller til en. For denne artikkelens formål, er den viktigste dimensjonen knyttet til den abstrakte retten til tankefrihet at personer har en rett til å gjøre seg opp sine egne oppfatninger om hva man vil tro på og hva man mener er verdifullt og verdt å gjøre.

Retten til tankefrihet og kravet om synspunktnøytralitet er helt vesentlige i et liberalt demokrati. Et demokrati - eller et folkestyre - krever politisk tankefrihet. ${ }^{28}$ Det vil si at borgerne har en rett til å gjøre seg opp sine egne oppfatninger om politiske saker, problemer og ideer. Synspunktbaserte restriksjoner på politiske ytringer, som et forbud mot oppfordringer til terrorisme, representerer en form for politisk tankekontroll. Målet for slike restriksjoner er vanligvis å forhindre at borgere utvikler (eller tilegner seg) farlige eller giftige ideer og synspunkter, som kan lede til farlige endringer i deres adferd. Synspunktbasert sensur innebærer at staten forsøker å kontrollere (a) hvilken informasjon og hvilke politiske ideer og synspunkter folk skal bli eksponert for, og (b) hvordan de skal tenke om visse politiske saker, ideer og mål - for eksempel for å forhindre voldelig radikalisering eller terrorisme. I et liberalt demokrati er denne formen for sensur av politiske ideer og synspunkter et uakseptabelt forsøk på å kontrollere folks tanker, som er i konflikt med deres demokratiske rett til politisk tankefrihet.

Et liberalt demokrati er et folkestyre, og man kan også argumentere for at et folke- styre forutsetter politisk tankefrihet og synspunktnøytralitet for å vise respekt for borgernes status som selvstendig tenkende styrere («rulers»). Et liberalt demokrati behandler ikke borgerne som styrere (eller respekterer deres status som styrere) hvis det ikke gir borgerne en rett til å gjøre seg opp sine egne oppfatninger om politikk i en åpen og fri deliberasjonsprosess. Dette innebærer at det er utillatelig for staten å fungere (eller spille rollen) som en ordstyrer for offentlig debatt og overveielse, som forbyr eller sensurerer de politiske ideene og synspunktene som borgerne skal tillates å uttrykke og høre. Hvis en stat sensurerer utvekslingen av politiske synspunkter på denne måten, så respekterer den ikke borgere som tenkende aktører og styrere, som har evnen og retten til å gjøre seg opp sine egne oppfatninger om politikk. Det virker både merkverdig og inkonsistent å anta at borgere $\mathrm{i}$ et demokrati har en rett til å styre, men samtidig behandle dem som om de mangler den nødvendige refleksjons- eller tenkeevne til å gjøre seg opp egne oppfatninger om politikk - slik at de bør beskyttes mot å bli eksponert for farlige ideer og synspunkter. Alexander Meiklejohn har et lignende poeng. $\AA$ si at folket i et demokratisk folkestyre bør «mentalt beskyttes» mot farlige ideer, synes å hvile på en antagelse om, eller en innrømmelse av, at de som er satt til å styre - nemlig folket - er «intellektuelt og moralsk uegnet» til å utføre denne oppgaven. ${ }^{29}$

\subsection{Argumentet basert på demokratisk legitimitet}

Det neste argumentet for en sterk beskyttelse av oppfordringer til terrorisme kan kalles argumentet basert på demokratisk legitimitet. Dette argumentet innebærer at legitim demokratisk utøvelse av politisk makt kre- 
ver synspunktnøytralitet med hensyn til politiske ytringer (inkludert ekstreme politiske ytringer) under omstendigheter preget av dyp uenighet.

Politisk legitimitet dreier seg om rettmessig utøvelse av politisk makt ${ }^{30}$ - det vil si den moralske begrunnelsen for utøvelse av politisk tvangsmakt. ${ }^{31}$ Et grunnleggende problem om politisk legitimitet er å forklare når statens utøvelse av politisk makt kan rettferdiggjøres. ${ }^{32}$ I et demokrati tilhører den politiske makten borgerne. Politisk makt er borgernes makt til å påtvinge hverandre lover og institusjoner under omstendigheter preget av uenighet. ${ }^{33}$ Dette aktualiserer spørsmålet om hvilke krav som bør stilles til en rettmessig demokratisk utøvelse av politisk makt.

Utgangspunktet for mitt argument basert på demokratisk legitimitet er de følgende tre antagelsene. ${ }^{34}$ Den første er at $\mathrm{i}$ et liberalt demokrati bør politiske institusjoner vise $r e$ spekt for borgere som tenkende aktører og styrere, som har en evne og en rett til å gjøre seg opp sine egne oppfatninger om politiske saker, problemer og ideer. Som allerede antydet, mener jeg at dette er en vesentlig dimensjon knyttet til å vise respekt for selvstendig tenkende personer i en politisk sammenheng.

Den andre antagelsen er at dyp uenighet er et vesentlig og permanent kjennetegn ved moderne liberal-demokratiske samfunn. Det er for eksempel uenighet om hvordan grunnleggende politiske, rettslige og økonomiske institusjoner bør organiseres, og hvordan slike institusjoner bør fordele goder og byrder (dvs. rettigheter, plikter, muligheter og ressurser). Dyp uenighet om rettferdighet og idealer om hva som er et godt samfunn, reflekteres for eksempel i debatter mellom liberale demokrater, kommunister, fascister og ulike grupper religiøse fundamentalister. Mer generelt kan man si at det foreligger dyp uenighet mellom individer og grupper om saker som er av stor betydning for dem i lys av deres grunnleggende moralske, politiske og religiøse overbevisninger.

Den tredje antagelsen er at politisk makt i et demokrati tilhører borgerne, og dette betyr at de kan utøve tvangsmakt over hverandre. Den måten borgere og deres valgte representanter utøver denne tvangsmakten (som kan anvendes av den demokratiske staten og dets håndhevingsapparat) har en betydelig innvirkning på interessene, målene, mulighetene og livsutsiktene til ulike individer og grupper, som har konkurrerende politiske doktriner (eller ideologier) og livssyn om hva som utgjør et meningsfullt og verdifullt liv. Til tross for at det foreligger dyp uenighet, er alle medlemmer av et demokratisk samfunn bundet av flertallets beslutninger - selv om de mener at disse beslutningene (og de politiske institusjoner som ligger til grunn for dem) er urettferdige og/eller i klar konflikt med deres grunnleggende moralske, politiske eller religiøse overbevisninger.

I lys av de skisserte antagelsene (om respekt for personer, dyp uenighet og politisk tvangsmakt), er det rimelig å betrakte det følgende som et grunnleggende krav til demokratisk legitimitet - det vil si et krav til rettmessig demokratisk utøvelse av politisk makt: I den deliberasjonsprosessen som former offentlig meningsdannelse $i$ et demokrati, bør alle borgere - inkludert upopulære og ekstreme dissentere som mange forakter - ha (a) frihet til å uttrykke sine politiske tanker og overbevisninger (dvs. talerautonomi) og (b) frihet til å høre, vurdere og respondere på andres politiske synspunkter (dvs. tilhørerautonomi). 
Dette kravet til demokratisk legitimitet er blant annet basert på tanken om at synspunktbasert sensur er i konflikt med respekt for personer som er dypt uenige (både som talere og tilhørere) og deres tankefrihet. Det foreslåtte kravet til demokratisk legitimitet er også nært knyttet til en idé om rettferdige («fair») demokratiske prosesser. Siden alle borgere er bundet av flertallets beslutninger, krever rettferdige demokratiske prosesser at alle parter i en debatt eller uenighet har muligheten til (a) å legge frem sine politiske synspunkter og (b) reflektere over og vurdere konkurrerende politiske synspunkter og deres styrker og svakheter.

I lys av respekt for personer som er dypt uenige og den politiske tvangsmakt borgere kan utøve over hverandre, så vil (hvis alt annet står likt) legitimiteten til den demokratiske utøvelsen av politisk makt undergraves dersom staten sensurerer ytringer av politiske tanker og synspunkter i den deliberasjonsprosessen som former offentlig meningsdannelse. Slik synspunktbasert sensur representerer en urettmessig (eller uakseptabel) demokratisk utøvelse av politisk makt som naturlig nok er spesielt problematisk med hensyn til dissentere som blir påtvunget institusjoner og lover som de avviser, og som er i klar konflikt med deres grunnleggende moralske, politiske eller religiøse overbevisninger.

De foregående betraktningene støtter antagelsen om at et forbud mot oppfordringer til terrorisme representerer en urettmessig (eller uakseptabel) demokratisk utøvelse av politisk makt, som undergraver den demokratiske legitimiteten til et liberal-demokratisk system. En viktig grunn til dette er at oppfordringer til terrorisme ofte reflekterer en dyptgående politisk misnøye, og slike politiske ytringer er ofte en del av en mer vidt- gående radikal kritikk av samfunnet og myndighetene, som er basert på mer omfattende (eller helhetlige) politiske og/eller religiøse doktriner og ideologier (jeg vil komme tilbake til dette aspektet ved oppfordringer til terrorisme i neste del). Denne typen politiske ytringer kan ikke utestenges fra politiske deliberasjonsprosesser gjennom sensur eller forbud uten å undergrave legitimiteten til den demokratiske utøvelsen av politisk makt.

Det bør understrekes at selv om et forbud mot oppfordringer til terrorisme vil undergrave den demokratiske legitimiteten til et liberal-demokratisk system, så betyr ikke dette at et slikt forbud i seg selv (eller isolert sett) vil fullstendig ødelegge legitimiteten til et liberal-demokratisk system betraktet som en helhet. Slik synspunktbasert sensur av politiske ytringer som blant annet finnes i Norge og Storbritannia, undergraver disse liberal-demokratiske statenes demokratiske legitimitet - i den forstand at en slik utøvelse av politisk makt er kritikkverdig. Denne utøvelsen av politisk makt er blant annet kritikkverdig fordi den er i konflikt med de ovennevnte normative ideene om rettferdige demokratiske prosesser og respekt for selvstendig tenkende personer som er dypt uenige. Det ville derimot være for sterkt å hevde at Norge og Storbritannias forbud i seg selv er tilstrekkelig for å ødelegge disse liberaldemokratiske statenes politiske legitimitet i den forstand at et forbud mot oppfordringer til terrorisme fullstendig river bort (1) det normative grunnlaget for å utøve politisk tvangsmakt over borgerne og (2) det normative grunnlaget for borgernes politiske forpliktelser til å adlyde lover. Når det er sagt, så ville imidlertid både Norge og Storbritannia vært mer legitime (og mindre kritikkverdige) liberal-demokratiske stater der- 
som de hadde opphevet sine synspunktbaserte restriksjoner på politiske ytringer.

\subsection{Argumentet basert på ekstreme politiske ytringers verdi}

I del 3.2 presenterte jeg argumentet basert på ytringers verdi - det vil si argumentet om at oppfordringer til terrorisme ikke bør beskyttes fordi slike ytringer er verdiløse. I det følgende vil jeg legge frem to delvis relaterte responser på dette argumentet.

(i) En Mill-inspirert respons: Selv doktriner eller meninger som mange, eller de fleste, betrakter som usanne, umoralske og verdiløse, kan utgjøre verdifulle bidrag til frie og velinformerte intrapersonlige og interpersonlige deliberasjonsprosesser. Dette er en sentral antagelse i John Stuart Mills forsvar av ytringsfrihet og tankefrihet. Ifølge Mill er ytringsfrihet viktig for å forhindre at sanne ideer og synspunkter blir uimotsagte dogmer som mister sin mening. For å unngå dette, bør liberale demokratier skape rammevilkår for at ideer og synspunkter gjøres til gjenstand for en åpen kamp - hvor konkurrerende perspektiver fremmes med kraft og alvor, og hvor alternative tanker og argumenter kan stimulere til kritisk deliberasjon eller overveielse. ${ }^{35}$ Dette gjelder alle doktriner og ideer - inkludert liberal-demokratiske ideer og verdier. "[T]here ought to exist the fullest liberty of professing and discussing, as a matter of ethical conviction, any doctrine, however immoral it may be considered». ${ }^{36}$

Mills ideer utgjør tungtveiende grunner for ikke å forstumme radikale ekstreme dissentere, som mange misliker eller forakter. En viktig grunn for dette er at sensur av politiske ideer og synspunkter kan undergrave utviklingen av våre deliberative evner (dvs. våre evner til tenkning og refleksjon). Å bli eksponert for konkurrerende ideer og argumenter, som fremmes med kraft og alvor, er vesentlig for utviklingen av våre deliberative evner. Radikale ekstreme dissentere, som avviser og problematiserer politisk rettroenhet (dvs. ortodokse politiske oppfatninger og ideer), formidler utfordrende og kontroversielle bidrag til politiske deliberasjonsprosesser. A forby eller sensurere ekstreme politiske ytringer kan således ha negative effekter med hensyn til vår interesse $\mathrm{i}$ a ha gode rammevilkår for å utvikle og forme våre oppfatninger (se også del 4.1. om «deliberative interesser» og «demokratiske verdier»).

(ii) Dyp politisk misnøye og verdien av radikal politisk kritikk: I vår tid reflekterer oppfordringer til terrorisme gjerne en dyp politisk misnøye - for eksempel med vestlige liberal-demokratiske samfunn og deres innenriks- og utenrikspolitikk. Denne dype politiske misnøyen er ofte basert på mer omfattende politiske og/eller religiøse doktriner og ideologier, som har en radikal og ekstrem karakter. I liberale demokratier bør denne misnøyen og de doktrinene som utgjør dens basis, tas alvorlig. Dette representerer i vår tids pluralistiske samfunn viktige politiske temaer og problemer, som bør gjøres til gjenstand for en åpen og fri offentlig debatt og ikke fordrives under jorden eller inn $i$ lukkede rom. Det er viktig og verdifullt å konfrontere politisk misnøye og dens underliggende ideer direkte i en åpen offentlig debatt og overveielse. I denne sammenhengen kan det være verdt å nevne Thomas Healys interessante respons på Richard Posners påstand om at oppfordringer til hellig krig ikke har noen verdi $i$ et liberalt demokrati som USA:

Many of the issues addressed by Islamic ji- 
hadists - the role of religion in society, the conflict between religious and secular values, the decline of morality - are extremely relevant within Western society. In fact, the battle between fundamentalism and liberalism that has fuelled Islamic jihad has also sparked a culture war in the United States. It is true that the methods advocated by Islamic jihadists are extreme and radical. But that does not make their speech less valuable, only more unsettling. And suppressing speech because it is unsettling is contrary to the best aspects of our First Amendment tradition. ${ }^{37}$

De som oppfordrer til terrorisme, betrakter gjerne terrorhandlinger som berettigede midler for å fremme eller oppnå politiske endringer, og deres oppfordringer til ulovlig vold er ofte en del av en mer omfattende radikal kritikk av samfunnet eller myndighetene. Verdien knyttet til oppfordringer til terrorisme er ikke hovedsakelig relatert til selve «oppfordringen" til ulovlig vold i seg selv, men til de premissene (dvs. antagelsene eller ideene) som ligger til grunn for oppfordringen til ulovlig vold. Dette poenget er inspirert av Harry Kalvens interessante diskusjon av det han kaller problemet om «subversive advocacy» - problemet om ytringer som oppfordrer til vold og ulovlige handlinger som en politisk taktikk.

[C]ases of incitement as a political tactic involve a uniquely important countervalue: radical criticism of the government and the society. This countervalue emerges most clearly in the extreme instance, the crime of violent overthrow of the government. ... If a man is seriously enough at odds with the society to advocate violent overthrow, his speech has utility not because advocating violence is useful but because the premises underlying his call to action should be heard. He says something more than «Revolt! Revolt!» He advances premises in support of that conclusion. And those premises are worth protecting, for they are likely to incorporate serious and radical criticism of the society and the government. ${ }^{38}$

\section{Konklusjon}

I denne artikkelen har jeg diskutert spørsmålet om liberale demokratier bør beskytte offentlige politiske ytringer som oppfordrer til terrorisme. Selv om det finnes flere interessante argumenter for et forbud mot oppfordringer til terrorisme som fortjener seriøs vurdering, så utgjør ikke disse etter min oppfatning en overbevisende begrunnelse for et forbud. Jeg har argumentert for at liberale demokratier bør gi ekstreme politiske ytringer, som oppfordringer til terrorisme, en sterk beskyttelse. Min posisjon er basert på den antagelsen at ytringsfrihetens kjerneverdi (eller normative kjernegrunnlag) i et liberalt demokrati er å beskytte og fremme frie og velinformerte deliberasjonsprosesser. På grunnlag av ytringsfrihetens kjerneverdi har jeg utviklet tre argumenter for min posisjon: argumentet basert på tankefrihet, argumentet basert på demokratisk legitimitet, og argumentet basert på ekstreme politiske ytringers (positive) verdi. 


\section{Noter}

I Jeg vil takke Kjartan Koch Mikalsen, Harald Ekeli, Espen Gamlund, Brian Garvey, Steven Heyman, Andrew March, Brynjar Meling og Jonathan Quong for verdifulle diskusjoner og kommentarer under arbeidet med denne artikkelen.

2 Intrapersonlig deliberasjon viser til et individs «interne» refleksjoner eller overveielser for eksempel om politiske saker, problemer og ideer. Et eksempel er en persons refleksjoner når vedkommende leser en avis eller ser en politisk diskusjon på TV og vurderer argumenter for og mot ulike synspunkter. Interpersonlig deliberasjon viser til diskusjonsprosesser hvor flere personer deltar (dvs. interpersonlig kommunikasjon) - for eksempel debatter i et parlament eller andre offentlige fora.

3 Brandenburgtesten ble formulert av den amerikanske høyesterett i den berømte saken Brandenburg v. Obio (1969): «[T] he constitutional guarantees of free speech and free press do not permit a State to forbid or proscribe advocacy of the use of force or of law violation except where such advocacy is directed to inciting or producing imminent lawless action and is likely to incite or produce such action». Brandenburg v. Ohio, 395 U.S. 444 (1969), 447.

4 Se Terrorism Act 2006, $\mathbb{S}$ 1. Et tilsvarende skille mellom direkte og indirekte oppfordringer trekkes i Ot.prp. nr. 8 (2007-2008), del 8.8.5.4.

5 Kent Greenawalt, Speech, Crime, and the Uses of Language. Oxford: Oxford University Press, 1989 , s. 271.

6 Heretter vil jeg for enkelthets skyld stort sett bruke termen «oppfordringer til terrorisme» i stedet for betegnelsen «offentlige politiske oppfordringer til terrorisme».

7 Det er interessant å merke seg at både FNs sikkerhetsråd og Europarådet i etterkant av terrorangrepene 11. september 2001 har tatt til orde for at medlemsstater bør innføre lover som forbyr oppfordringer til terrorisme. Se for eksempel FNs sikkerhetsråds resolusjon 1624 (14. september 2005) og Europarådskonvensjon om forebygging av terrorisme (16. mai 2005).

8 Blant de stater som forbyr forherligelse eller glorifisering av terrorisme er Frankrike, Spania og Storbritannia.

9 Straffeloven $\$ 140$ forbyr både direkte og indirekte oppfordringer til straffbare handlinger, som terrorhandlinger. Straffeloven $\$ 147 \mathrm{c}$ forbyr offentlige oppfordringer til terrorisme med den hensikt å skape alvorlig frykt i en befolkning eller urettmessig å tvinge offentlige myndigheter til å gjøre, tåle eller unnlate noe av vesentlige betydning for landet. Io «Voldelig radikalisering» vil her vise til prosesser som leder til at personer (over tid) begynner å støtte terroristorganisasjoner og terrorisme som legitime eller akseptable midler for å fremme politiske og/eller religiøse mål.

I I Flere aspekter ved de refleksjoner og argumenter som fremsettes her, vil utdypes i del 4.

I 2 En rettighets rekkevidde viser til hva den er en rett $t i l$. En rettighets status viser til rettighetens vekt (eller styrke) når den kommer i konflikt med andre etiske hensyn - f.eks. andre rettigheter, moralske plikter eller verdier.

I3 Rawls, Political Liberalism. New York: Colombia University Press, 1993, ss. 354 og 349. Disse refleksjonene er delvis knyttet til faren for maktmisbruk i forbindelse med sensur og regulering av politiske ytringer - spesielt politiske synspunkter og ideer som er upopulære eller som fremsettes av upopulære dissentere som mange misliker og forakter.

I4 Posner, Not a Suicide Pact: The Constitution in a Time of National Emergency. Oxford: Oxford University Press, 2006, s. 113, mine uthevinger.

I 5 Fein, "Criminal Speech», The Washington Times, 8. august 2005.

I6 Se Heyman, Free Speech and Human Dignity. New Haven: Yale University Press, 2008 og «Hate Speech, Public Discourse and the First Amendment", i; I. Hare og J. Weinstein (red.), Extreme Speech and Democracy. Oxford: Oxford University Press, 2009, ss. 158-181; og Quong, «The Rights of Unreasonable Citizens", Journal of Political Philosophy, 2004, 12(3): 314-335 og Liberalism Without Perfection. Oxford: Oxford University Press, 2011, kap. 10.

I7 Hverken Heyman eller Quong diskuterer oppfordringer til terrorisme.

I 8 Antagelsen er her at det er en nær sammenheng mellom en rettighets begrunnelse (dvs. det normative grunnlaget for en rettighet) og rettighetens rekkevidde - i den forstand at det normative grunnlaget for rettigheten legger føringer på hvordan rettighetens rekkevidde spesifiseres (dvs. hvordan man spesifiserer hva rettigheten er en rett til).

I9 Ifølge Quong er det urimelig («unreasonable») å bruke (valgbeskyttende) rettigheter på denne måten, og personer har ingen rett til å være urimelige (se Quong 2004: 332).

20 Både Heyman og Quong konkluderer med at hatefulle ytringer er respektbenektende ytringer 
som faller utenfor rekkevidden til retten til ytringsfrihet. Se Heyman 2009: 177 og Quong 2004: 329, note 44.

2I Se for eksempel Ronald Dworkin, Justice for Hedgehogs. Cambridge, Mass.: Harvard University Press, 2009 og «Foreword», i; I. Hare og J. Weinstein (red.), Extreme Speech and Democracy. Oxford: Oxford University Press, 2011, ss. vix; John Stuart Mill, On Liberty. London: Penguin Books, 1985/1859; Thomas Nagel, Concealment and Exposure. Oxford: Oxford University Press, 2002; Rawls (1993); og Thomas Scanlon, The Difficulty of Tolerance. Cambridge: Cambridge University Press, 2003.

22 I det følgende vil jeg legge til grunn følgende forståelse av fri og velinformert diskusjon - dvs. fri og velinformert interpersonlig deliberasjon:

«[F]ree discussion refers to a process of interpersonal deliberation that is open; that does not constrain the exchange and dissemination of information, ideas and perspectives; and that does not constrain or impair intrapersonal deliberation or critical reflection on the issue(s) under discussion - e.g. through pressure, threats, deception, manipulation or indoctrination. Well-informed discussion refers to a process of interpersonal deliberation where the participants are exposed to and take into account a diversity of information, ideas and perspectives that are relevant for critical and rational reflection on the issue(s) under consideration. Whether discussion is free and well-informed in the outlined sense is a matter of degree» (Ekeli, «Liberalism and Permissible Suppression of Illiberal Ideas», Inquiry, 2012, 55(2): 180).

23 Beskyttelsen av slike deliberasjonsprosesser (spesielt intrapersonlig deliberasjon) er nært knyttet til retten til tankefrihet generelt og politisk tankefrihet spesielt. Jeg vil komme tilbake til dette temaet i del 4.2.

24 Se også Scanlon 2003: 91, Mill 1985/1859: 115116 og Ekeli 2012: 181.

25 Dette er et sentralt poeng i John Stuart Mills kjente teori om ytringsfrihet. Se f.eks. Mill 1985/ 1859: 115-116.

26Ideen om respekt for personers autonomi spiller en vesentlig rolle i flere statusbaserte begrunnelser for rettigheter generelt og retten til ytringsfrihet spesielt. Se f.eks. Nagel (2002) og Corey Brettschneider, Democratic Rights. Princeton: Princeton University Press, 2007.

27 I denne sammenhengen kan man trekke et skille mellom tre typer restriksjoner på ytringer. Inn- holdsnøytrale restriksjoner viser til restriksjoner som ikke er relatert til (eller basert på) ytringens innhold eller budskap. Et eksempel er restriksjoner på tidspunkt og sted for politiske demonstrasjoner (På engelsk omtales dette ofte som «time, place and manner restrictions»). Innholdsbaserte restriksjoner refererer derimot til restriksjoner som er basert på ytringens innhold eller budskap. Alle innholdsbaserte restriksjoner er imidlertid ikke synspunktbaserte. For eksempel er et forbud mot politisk reklame på TV innholdsbasert, men synspunktnøytralt. Synspunktbaserte restriksjoner er en underkategori av innholdsbaserte restriksjoner som legger restriksjoner på kommunikasjonen av visse bestemte synspunkter eller ideer. For interessante diskusjoner av disse typene restriksjoner, se f.eks. Geoffrey R. Stone, "Content Regulation and the First Amendment", William and Mary Law Review, 1983, 25(2): 189-252; og Cass Sunstein, Democracy and the Problem of Free Speech. New York: The Free Press, 1993, ss. 11-12.

28 Se også Brettschneider 2007: 45.

${ }_{29}$ Se Meiklejohn, Free Speech and Its Relation to Self-Government. New York: Harper Brothers Publishing, 1948, s. xiv.

30 Politisk makt viser her til makt eller myndighet til å lage, anvende og håndheve lover, og disse lovene kan håndheves med tvang. Som Rawls påpeker, er tvang en vesentlig dimensjon ved politisk makt: «Political power is always coercive power backed by the government's use of santions» (Rawls 1993: 136).

3 I Se også Rawls (1993: 136-137); Allen Buchanan, «Political Legitimacy and Democracy», Ethics, 2002, 112(4): 689-719; og Dworkin (2011: 321, 330 og 372).

32 I politisk filosofi antar mange at en legitim utøvelse av politisk makt skaper politiske forpliktelser (eller prima facie politiske forpliktelser) til å adlyde lover. Alle aksepterer imidlertid ikke denne antagelsen, og det finnes ulike syn på forholdet mellom politisk legitimitet og politiske forpliktelser.

33 Se også Rawls 1993: 136.

34 Noen aspekter ved dette argumentet er relatert til argumentet basert på tankefrihet.

35 Se Mill 1985/1859: 116.

36 Mill 1985/1859: 75.

37 Healy, «Brandenburg in a Time of Terror», Notre Dame Law Review, 2009, 84(2): 31.

38 Kalven, A Worthy Tradtion. New York: Harper and Row Publishers, 1988, s. 120. Se også Rawls 1993: 364. 